\title{
Effects of organic fertilizers on yam productivity and some soil properties of a nutrient-depleted tropical Alfisol
}

\author{
T.M. Agbede ${ }^{a}$, A.O. Adekiya ${ }^{b}$ and J.S. Ogeh ${ }^{\mathrm{c}}$ \\ ${ }^{a}$ Department of Agricultural Technology, Rufus Giwa Polytechnic, Owo, Nigeria; ${ }^{b}$ Department \\ of Crop, Soil and Pest Management, Federal University of Technology, Akure, Nigeria; \\ ${ }^{c}$ Department of Soil Science, University of Benin, Benin city, Nigeria
}

(Received 6 December 2011; final version received 31 March 2012)

\begin{abstract}
Field experiments were conducted at Owo, southwest Nigeria to select organic fertilizer treatments most suitable for sustaining high soil fertility and yam productivity on a nutrient-depleted tropical Alfisol. Eight organic fertilizer treatments were applied at $20 \mathrm{t} \mathrm{ha}^{-1}$ with a reference treatment inorganic fertilizer (NPK 15-15-15) at $400 \mathrm{~kg} \mathrm{ha}^{-1}$ and natural soil fertility (control), laid out in a randomized complete block design with three replications. Results showed that organic fertilizers significantly increased $(p=0.05)$ tuber weight and growth of yam, soil and leaf $\mathrm{N}, \mathrm{P}, \mathrm{K}, \mathrm{Ca}$ and $\mathrm{Mg}$, soil $\mathrm{pH}$ and organic $\mathrm{C}$ concentrations compared with the NSF (control). The oil palm bunch ash + poultry manure treatment increased tuber weight, vine length, number of leaves and leaf area of yam by $66,25,21$ and $52 \%$, respectively, compared with inorganic fertilizer (NPK) and 37, 22, 19 and 44\%, respectively, compared with poultry manure alone. Sole or mixed forms of organic fertilizers showed significant improvement in soil physical conditions compared with IF (NPK) and NSF (control). Synergistic use of oil palm bunch ash + poultry manure at $10 \mathrm{t} \mathrm{ha}^{-1}$ each was most effective for sustainable management of soils and for improving agronomic productivity of yam.
\end{abstract}

Keywords: organic fertilizer; soil properties; yam; leaf nutrient content; Nigeria

\section{Introduction}

Yam (Dioscorea rotundata Poir) belongs to the family Dioscoreaceae and is a crop grown for its edible tubers, which is an important stable food in West Africa. Yam is of particular importance for the people of Africa, who derive $\sim 15 \%$ of their total dietary calories from tuber crops (Howeler et al. 1993). Yam is second to cassava as the most important and cultivated tropical tuber crop in Nigeria. Because of its multipurpose uses, it occupies a principal place in farming the humid tropical region. Whereas Africa alone is responsible for $90 \%$ of the world production of yam; Nigeria accounts for over $70 \%$ of world production (Okoh 2004; Vernier and Dansi 2000; Agbede 2006). Yam tubers are eaten boiled, fried, mashed or pounded. Yam flour is the best form to preserve and store yams.

*Corresponding author. Email: agbedetaiwomichael@yahoo.com 
Yams require a relatively rich soil, particularly in terms of organic matter and soil nutrients (Degras 1993; Howeler et al. 1993), in order to perform well. Because of their high demand for nutrients, yams are traditionally the first crops grown after fallow (Orkwor et al. 1998). The limitations imposed on soil productivity in the tropics, in terms of loss of fertility and pressure on land use due to non-agricultural development, is forcing farmers to cultivate degraded or depleted soils for yam production. It is therefore necessary to explore alternative means to improve the nutrient status of these soils. In sub-Saharan tropical Africa, the maintenance of soil productivity remains a knotty issue due to poor cultural practices, the fragile nature of most arable soils and poor organic matter and available nutrient status (Nottidge et al. 2005; Agbede and Ojeniyi 2009). Bationo et al. (2006) described soil fertility depletion as the single most important constraint on food security in West Africa. All efforts to maintain soil nutrients with chemical fertilizers alone in order to sustain high crop yield are hindered by the high cost of purchasing fertilizers, especially for resource-poor farmers, acute scarcity during planting and the destruction of soil properties arising from continuous use (Aduayi 1980).

According to Yadav and Prassad (1992), the tendency to supply all plant nutrients through synthetic fertilizers should be avoided as this has a deleterious effect on long-term soil productivity. It also enhances soil acidity, nutrient leaching, nutrient imbalance and degradation of soil physical properties and organic matter (Ojeniyi 2000; Agbede et al. 2008). Soil degradation, which is brought about by a loss of organic matter accompanying continuous cropping, is aggravated when chemical fertilizers are applied repeatedly. This is because the crop response to applied fertilizer depends on soil organic matter (Agboola and Omueti 1982).

The need to use renewable forms of energy and reduce the costs associated with fertilizing crops has revived the use of organic fertilizers worldwide. Improvements in environmental conditions and public health are important reasons for advocating the increased use of organic materials (Ojeniyi 2000; Maritus and Vleic 2001). Gruhn et al. (2000) suggested that future strategies for increasing agricultural productivity from available land resources will have to focus on using available nutrient resources more efficiently, effectively and sustainably than in the past. Integrated management of nutrients needed for proper plant growth, together with effective crop, water, soil and land management will be critical for sustaining agriculture over the long-term. In a sustainable low-input agricultural system, where nutrient depletion is a serious constraint to crop production, the use of organic fertilizers such as oil palm bunch ash, spent grain (sorghum-based brewery waste), poultry and goat manures is inevitable. Soils have to be amended and managed in a special manner to be cultivated profitably. The effect of different organic fertilizer materials on the actual yield of yam has not yet been properly documented. The current average gross tuber yield is low, being estimated at $\sim 10$ metric tons $(\mathrm{Mt}) \mathrm{ha}^{-1}$. This implies that more research is needed to increase production to appreciable levels in order to meet global demand for yam. Use of organic fertilizers that are cheap, sustainable, edaphologically suitable, economically viable, culturally acceptable, environmentally friendly and compatible is considered a major method of increasing yam yield on a unit per area basis.

Organic manures are known to be effective in the maintenance of an adequate supply of organic matter into soil, with attendant improvement in soil physical and chemical conditions and enhanced crop performance (Ikpe and Powel 2003; Ano and Agwu 2005). Enormous quantities of organic wastes such as poultry manure, goat 
manure, spent grain and oil palm bunch ash are available in Nigeria where they pose disposal problems and environmental hazards, and are at the same time effective sources of nutrients for tuber crops like yam. Except for Adu-Dapaah et al. (1994), Moyin-Jesu and Atoyoseye (2002), Ojeniyi et al. (2007), Agbede and Ojeniyi (2009) and Ayeni et al. (2008) who reported the use of ash of cocoa husk, spent grain, goat manure, poultry manure, and saw dust and wood ash to grow maize, cocoa seedlings, tomato, sorghum and cocoa seedlings, respectively, research information on the use of goat and poultry manures, oil palm bunch ash and spent grain for the production of yam is yet to receive research attention. Yam is very exerting on soil moisture and nutrient levels, and the root volume per plant extends more deeply and more broadly than other crops, e.g. cereals (Onwueme 1978). Therefore, continuous cultivation of a crop like yam on the same land will lead to soil mining, degradation of soil quality and consequent low yield. According to Obigbesan and Agboola (1978), for a target yield of $37.9 \mathrm{t} \mathrm{ha}^{-1}$, yam removes $148.0,41.2$ and $199.2 \mathrm{~kg} \mathrm{ha}^{-1}$ of $\mathrm{N}, \mathrm{P}$ and $\mathrm{K}$, respectively, from soil. This calls for fertility-enhancing technologies including the application of organic manures/fertilizers. Thus, it is expected that application of organic fertilizers would enhance soil fertility and performance of yam. Organic fertilizers could also help by reducing soil acidity where necessary (Samuel et al. 2003; Moyin-Jesu and Adeofun 2008). Hence, the objective of this study was to evaluate the effects of no fertilizer, inorganic fertilizer and different organic fertilizers alone and in combination on soil and crop chemical composition, growth and yield of yam grown on an Alfisol of southwestern Nigeria.

\section{Materials and methods}

\section{Site description, the trial design and duration, the treatments, field layout and crop husbandry}

The experiments were carried out at the Teaching and Research Farm of Rufus Giwa Polytechnic, Owo, Ondo State, southwestern Nigeria at latitude $7^{\circ} 12^{\prime} \mathrm{N}$, longitude $5^{\circ} 35^{\prime} \mathrm{E}$. Available weather data indicate that the annual rainfall totals (mm) were 1335, 1346 and 1547 for 2007, 2008 and 2009, respectively. The rainy season starts in March, and lasts until October, while the dry season is between November and February, with temperatures ranging from 24 to $32^{\circ} \mathrm{C}$. The soil of the experimental site belongs to an Alfisol classified as Oxic Tropuldalf (USDA 2010) or Luvisol (FAO 1998) derived from quartzite, gneiss and schist (Agbede 2006). Composite upper soil layer $(0-15 \mathrm{~cm})$ samples from the experimental site were taken to determine the physical and chemical properties of the soil before cropping. A vaierty of crops were grown at the site including cassava (Manihot esculenta Crantz), cowpea (Vigna unguiculata Walp), maize (Zea mays L.), melon (Colosynthis citrullus L.), etc. for at least 12 years without fertilizer application before the initiation of this study. The trials were conducted for three cropping seasons, 2007, 2008 and 2009, on the same site.

Each year, the experiment consisted of 10 treatments, concerned with three main comparisons - natural soil fertility (NSF, the control), soil with inorganic fertilizer (IF) added, and soil with organic fertilizers added, which, in turn, had three comparisons: animal manures (goat manure, GM, and poultry manure, PM), plantderived residues (oil palm bunch ash, OBA, spent grain, SG and mixtures of the two, OBA with GM and PM; SG with GM and PM). The organic manures were applied at $20 \mathrm{tha}^{-1}$, based on recommendation for high nutrient requiring tuber crop like 
yam (NRCRI 1982; Onweremadu et al. 2008) while inorganic fertilizer was applied at $400 \mathrm{~kg} \mathrm{ha}^{-1}$, based on field recommendation for yam production on a nutrientdepleted soil (FPDD 1989). Doses of organic materials were expressed on a fresh weight basis. The 10 treatments compared were: (1) control, NSF, a relatively degraded soil condition because of prior land use; (2) IF (NPK 15-15-15; 15 N, 15 $\mathrm{P}_{2} \mathrm{O}_{5}, 15 \mathrm{~K}_{2} \mathrm{O}$ ) at $400 \mathrm{~kg} \mathrm{ha}^{-1}$; (3) $\mathrm{GM}$ at $20 \mathrm{t} \mathrm{ha}^{-1}$; (4) $\mathrm{PM}$ at $20 \mathrm{t} \mathrm{ha}^{-1}$; (e) OBA (waste product after the incineration of palm bunch refuse after fruit extraction containing $\mathrm{N}$ and $\mathrm{K}$ ) at $20 \mathrm{t} \mathrm{ha}^{-1}$; (6) SG at $20 \mathrm{t} \mathrm{ha}^{-1}$; (7) OBA at $10 \mathrm{t} \mathrm{ha}^{-1}$ mixed with GM at $10 \mathrm{t} \mathrm{ha}^{-1}$; (8) OBA at $10 \mathrm{tha}^{-1}$ mixed with PM at $10 \mathrm{t} \mathrm{ha}^{-1}$; (9) SG at $10 \mathrm{tha}^{-1}$ mixed with GM at $10 \mathrm{t} \mathrm{ha}^{-1}$; and (10) SG at $10 \mathrm{t} \mathrm{ha}^{-1}$ mixed with PM at $10 \mathrm{tha}^{-1}$. The 10 treatments were laid out in a randomized complete block design and replicated three times.

After manual clearing and packing of debris away from the site, soil mounds were formed at a $1 \times 1 \mathrm{~m}$ spacing in April each year. Each mound was $\sim 1 \mathrm{~m}$ wide at the base and $\sim 0.75 \mathrm{~m}$ high. The size of each of the 30 plots was $6 \times 6 \mathrm{~m}$, giving a plant population of 36 plants per plot. Blocks were $1 \mathrm{~m}$ apart and the plots were 0.5 $\mathrm{m}$ apart. Planting was done immediately after construction of the mounds in each year. One seedyam weighing $\sim 0.4 \mathrm{~kg}$ of white yam (Dioscorea rotundata cv Gambari) was planted per hole on 3 April 2007, 6 April 2008 and 8 April 2009. The organic fertilizers were applied in a ring form at planting, and thoroughly worked into the soil with a hoe. NPK 15-15-15 fertilizer was applied in a ring form in two equal doses. The first dose was applied at 1 month after vine emergence, and the second 8 weeks later when tuber expansion, rapid stem and leaf development were in progress. Stakes were installed after sprouting. Weeding was manual with a hoe at 3 , 8, 12 and 16 weeks after planting in each experiment.

Ten plants were randomly selected per plot for determination of vine length, number of leaves and leaf area at 5 months after planting when the yam plant formed a full canopy. Vine length was determined by meter rule. Number of leaves was determined by counting the number of leaves on each yam plant and the leaf area was measured using a graphical method (i.e. by placing the leaf on graph sheet for area determination). Tuber yield was determined at harvest (8 months after planting) by recording the weight of fresh tuber from 10 plants selected randomly from each plot using a top loading balance to determine their weights.

\section{Soils, soil inputs and leaf analysis of yam plant}

Two months after planting yam, determination of bulk density, total porosity and gravimetric water content in all plots was commenced and repeated at 2-month intervals on four occasions for each year. Five undisturbed samples $(4 \mathrm{~cm}$ diameter, $15 \mathrm{~cm}$ high) were collected at $0-15 \mathrm{~cm}$ depth from the centre of each plot at random and $\sim 15 \mathrm{~cm}$ away from each yam mound using steel coring tubes; the samples were used to evaluate bulk density, total porosity and gravimetric water content after oven-drying at $100^{\circ} \mathrm{C}$ for $24 \mathrm{~h}$. Total porosity was calculated from the bulk density and particle density of $2.65 \mathrm{Mg} \mathrm{m}^{-3}$.

Before the start of the experiment in 2007, surface soil $(0-15 \mathrm{~cm})$ samples were randomly collected from 10 different points on the experimental site. Disturbed soil samples were collected randomly at $0-15 \mathrm{~cm}$ depth from the centre of each plot on mounds at five sites per plot at harvest in 2009 (third crop). The soil samples were bulked, air-dried and sieved using a $2-\mathrm{mm}$ sieve for routine chemical analysis, as 
described by Carter (1993). Particle-size analysis was carried out for textural class using the hydrometer method (Sheldrick and Hand Wang 1993). Soil pH was determined in a soil/water (1: 2) suspension using a digital electronic $\mathrm{pH}$ meter. Soil organic carbon was determined by the Walkley and Black procedure by wet oxidation using chromic acid digestion (Nelson and Sommers 1996). Total N was determined using micro-Kjeldahl digestion and distillation techniques (Bremner 1996), available P was determined by Bray-1 extraction followed by molybdenum blue colorimetry (Frank et al. 1998). Exchangeable K, Ca and Mg were extracted with a $1 \mathrm{M} \mathrm{NH}{ }_{4} \mathrm{OAc}$, pH 7 solution. Thereafter, $\mathrm{K}$ was analysed with a flame photometer and $\mathrm{Ca}$ and $\mathrm{Mg}$ were determined with an atomic absorption spectrophotometer (Okelabo et al. 2002).

Oil palm bunch ash was obtained from the oil palm processing unit at the Ondo State Agricultural Development Project, Owo, and spent grain (sorghum-based brewery waste) was collected from a nearby local brewery. The poultry and goat manures were obtained from livestock pens at Rufus Giwa Polytechnic, Owo. The organic materials were processed to allow decomposition. Goat manure was ground to allow quick mineralization. The oil palm bunch ash was sieved to remove pebbles, stones and unburnt shafts, and the spent grain was partially composted for 6 weeks to reduce the $\mathrm{C} / \mathrm{N}$ ratio. Poultry manure was stacked under a shed for 1 week to allow quick mineralization. In general, all the organic wastes are readily available, sustainable and inexpensive for growing commercial quantities of yam.

Small $\sim 2 \mathrm{~g}$ subsamples of each of the processed forms of the organic materials used in the experiments were analysed to determine their nutrient composition. The samples were air-dried and crushed to pass through a 2-mm sieve before analysis. The samples were analysed for organic C, total N, P, K, Ca and Mg. The percentage organic carbon was determined by the Walkely and Black procedure using the dichromate wet oxidation method (Nelson and Sommers 1996), total N was determined by micro-Kjeldahl digestion, followed by distillation and titration (Bremner 1996) while the determination of other nutrients such as total P, K, Ca and $\mathrm{Mg}$ was done using the wet digestion method based on 25-5-5 $\mathrm{mL}$ of $\mathrm{HNO}_{3}-\mathrm{H}_{2} \mathrm{SO}_{4}-\mathrm{HClO}_{4}$ acids (Horwitz 1997). Phosphorus was measured colorimetrically by the molybdate blue method in an auto-analyser, $\mathrm{K}$ by flame photometry, and $\mathrm{Ca}$ and $\mathrm{Mg}$ by atomic absorption spectrophotometer (Okalebo et al. 2002).

In the 2009 cropping season, representative leaf samples from the upper, middle and lower parts of the yam vines were randomly collected from five plants per plot at 5 months after planting for chemical analysis. The leaf samples were oven-dried at $70^{\circ} \mathrm{C}$ for $24 \mathrm{~h}$ before grinding in a Willey mill. Leaf $\mathrm{N}$ was determined by microKjeldahl digestion. Ground leaf samples were dry ashed at $450^{\circ} \mathrm{C}$ for $6 \mathrm{~h}$ in a muffle furnace and extracted using a $\mathrm{HNO}_{3}-\mathrm{H}_{2} \mathrm{SO}_{4}-\mathrm{HClO}_{4}$ mixture to determine $\mathrm{P}, \mathrm{K}$ $\mathrm{Ca}$ and $\mathrm{Mg}$. Phosphorus was determined colorimetrically using the vanadomolybdate method. $\mathrm{K}$ was determined using a flame photometer and $\mathrm{Ca}$ and $\mathrm{Mg}$ were determined by the EDTA titration method (Horwitz 1997).

\section{Statistical analysis}

Data collected for yield and growth parameters, soil properties and leaf nutrient concentrations were subjected to analysis of variance (ANOVA) using SPSS 15.0 and Microsoft Office Excel 2007 packages, and the separation of treatment means were 
determined using Duncan's multiple range test (DMRT) and the least significant difference (LSD) at $p=0.05$ probability level (Steel et al. 1997).

\section{Results}

\section{Initial soil fertility status}

The physical and chemical properties of the soil $(0-15 \mathrm{~cm})$ at the experimental site before cropping are presented in Table 1. Based on the established critical levels for soils in ecological zones of Nigeria, the soil was acidic with pH 5.4 (Moyin-Jesu and Adeofun 2008), compared with $\mathrm{pH}$ values of between 6.0 and 7.0 considered as optimum for yam cultivation (Shiwachi et al. 2004). The soil was low in organic carbon (OC), total $\mathrm{N}$, available $\mathrm{P}$ and exchangeable $\mathrm{Ca}$, according to the critical levels

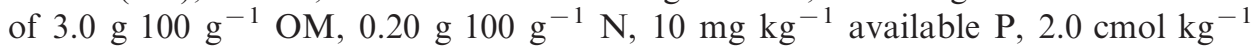
exchangeable $\mathrm{Ca}$ recommended for most crops (Akinrinde and Obigbesan 2000). The exchangeable $\mathrm{K}$ was less than the $0.15 \mathrm{cmol} \mathrm{kg}^{-1}$ critical level considered adequate for yam production (Okereke et al. 1987). The exchangeable $\mathrm{Mg}$ was lower than the $0.25-0.43 \mathrm{cmol} \mathrm{kg}^{-1}$ critical level considered as optimum for yam (Ohiri 1995), indicating poor soil fertility. The soil bulk density was high and the total porosity was low.

\section{Chemical properties of the organic fertilizers used in the experiment}

The chemical properties of the organic fertilizers used for yam production (means of three years, 2007-9) are shown in Table 2. PM had significantly higher $(p=0.05) \mathrm{N}$ and $\mathrm{P}$ nutrient concentrations and the lowest $\mathrm{C} / \mathrm{N}$ ratio of 7.4 compared with the other organic materials. GM was comparable with PM in organic C and K, but N, P, $\mathrm{Ca}$ and $\mathrm{Mg}$ in PM were significantly higher $(p=0.05)$ than in GM. OBA had significantly higher values of $\mathrm{K}, \mathrm{Ca}$ and $\mathrm{Mg}$ compared with PM, GM and SG. SG had the lowest values of $\mathrm{C}, \mathrm{N}, \mathrm{P}, \mathrm{K}, \mathrm{Ca}$ and $\mathrm{Mg}$, and the highest $\mathrm{C} / \mathrm{N}$ ratio of 12.8 .

\section{Effect of different organic fertilizers on yield of yam}

Organic fertilizers had a significant effect on tuber weight of yam in the 2007, 2008 and 2009 cropping seasons (Figure 1). In 2007, and among the sole forms of organic

Table 1. Mean \pm standard deviation of soil physical and chemical properties of $0-15 \mathrm{~cm}$ depth of the experimental site before experimentation.

\begin{tabular}{|c|c|}
\hline Soil property & Value \\
\hline 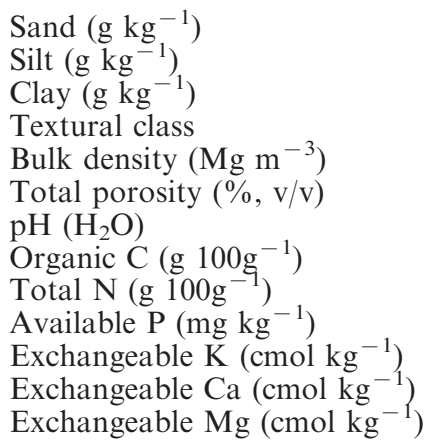 & $\begin{array}{r}675 \pm 7.4 \\
153 \pm 5.8 \\
172 \pm 4.9 \\
\text { Sandy loam } \\
1.61 \pm 0.08 \\
39.25 \pm 0.5 \\
5.4 \pm 0.2 \\
0.94 \pm 0.04 \\
0.08 \pm 0.01 \\
6.8 \pm 0.2 \\
0.14 \pm 0.02 \\
1.32 \pm 0.03 \\
0.15 \pm 0.01\end{array}$ \\
\hline
\end{tabular}


Table 2. Chemical composition of organic fertilizers used for growing yam related to dry mass.

\begin{tabular}{|c|c|c|c|c|c|c|c|}
\hline \multirow[b]{2}{*}{ Organic fertilizer } & $\mathrm{C}$ & $\mathrm{N}$ & \multirow{2}{*}{$\mathrm{C} / \mathrm{N}$ ratio } & $\mathrm{P}$ & $\mathrm{K}$ & $\mathrm{Ca}$ & $\mathrm{Mg}$ \\
\hline & \multicolumn{2}{|c|}{$(\%)$} & & \multicolumn{4}{|c|}{$(\%)$} \\
\hline Goat manure & $21.7 \mathrm{a}$ & $2.54 \mathrm{~b}$ & $8.5 \mathrm{c}$ & $0.85 \mathrm{c}$ & $1.71 \mathrm{~b}$ & $0.80 \mathrm{c}$ & $0.44 \mathrm{c}$ \\
\hline Poultry manure & $22.5 \mathrm{a}$ & $3.03 \mathrm{a}$ & $7.4 d$ & $1.4 \mathrm{a}$ & $1.80 \mathrm{~b}$ & $0.86 \mathrm{~b}$ & $0.58 \mathrm{~b}$ \\
\hline Oil palm bunch ash & $10.4 \mathrm{~b}$ & $1.76 \mathrm{c}$ & $10.5 b$ & $1.1 \mathrm{~b}$ & $2.10 \mathrm{a}$ & $0.93 \mathrm{a}$ & $0.70 \mathrm{a}$ \\
\hline Spent grain & $10.0 \mathrm{~b}$ & $0.78 \mathrm{~d}$ & $12.8 \mathrm{a}$ & $0.76 \mathrm{~d}$ & $0.56 \mathrm{c}$ & $0.13 \mathrm{~d}$ & $0.18 \mathrm{~d}$ \\
\hline
\end{tabular}

Note: Treatment means within each column followed by the same letters are not significantly different from each other at $p=0.05$ according to Duncan's multiple range test (DMRT).

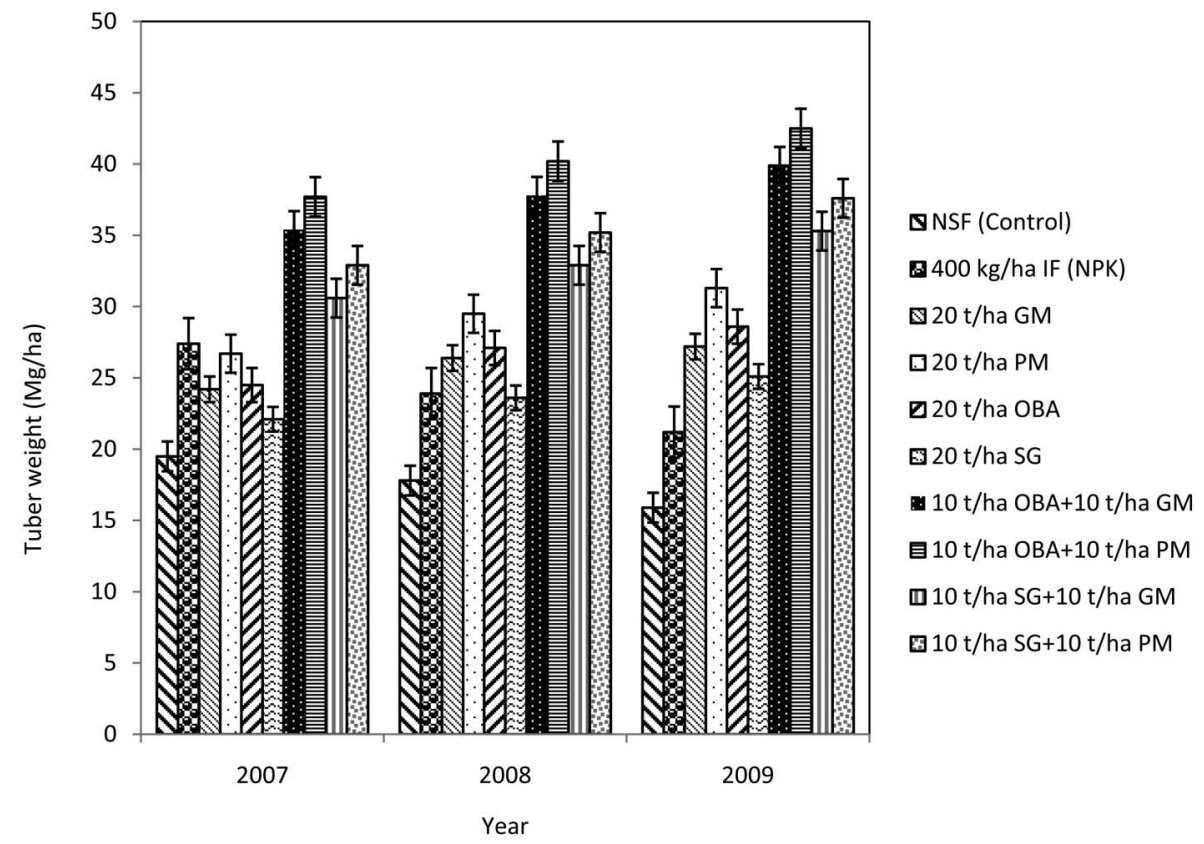

Figure 1. Tuber weight in 2007, 2008 and 2009 cropping seasons as affected by different organic fertilizers. Vertical bars show standard errors of paired comparisons.

fertilizers, the tuber weight of yam produced by PM was comparable with IF (NPK), which produced the highest tuber weight. The tuber weights produced by these treatments (IF and PM) were significantly higher $(p=0.05)$ than that of GM and SG. The NSF (control) treatment gave the lowest tuber weight and was significantly lower $(p=0.05)$ than other treatments.

However, the trend was reversed in the 2008 and 2009 cropping seasons (Figure 1). The PM treatment produced the highest tuber weight of yam, which was significantly higher $(p=0.05)$ than OBA, GM, IF and SG. The tuber weights of yam produced by OBA, GM and SG in these two years were significantly higher $(p=0.05)$ than IF, except for SG in 2008, which produced similar tuber weight of yam with IF. The lowest tuber weight of yam was also produced by NSF (control) treatment. 
In the 2007, 2008 and 2009 cropping seasons, mixtures of organic fertilizers gave significantly higher $(p=0.05)$ tuber weights than their sole forms (Figure 1). Among the mixtures, OBA + PM produced the highest tuber weight of yam, and this was significantly higher than $\mathrm{OBA}+\mathrm{GM}$ and $\mathrm{SG}+\mathrm{PM}$. Among the mixtures of organic fertilizers, $\mathrm{SG}+\mathrm{GM}$ gave the lowest tuber weight.

The tuber yield in the organic fertilizer regime treatments increased over time, whereas that under NSF (control) or soil under IF (NPK) regime treatment declined (Figure 1).

Averaged over the 3 years, OBA + PM increased the tuber weight of yam by $50 \%$ relative to OBA alone (Figure 2). $\mathrm{SG}+\mathrm{PM}$ increased tuber weight by $21 \%$ compared with PM alone. Relative to IF, OBA + PM increased tuber weight of yam by $66 \%$. OBA + PM also increased tuber weight of yam by $70 \%$ compared with SG. The IF treatment increased tuber weight of yam by $37 \%$ compared with the NSF (control), whereas PM increased tuber weight by $21 \%$ compared with IF.

\section{Economics of yam production under the different organic fertilizer treatments}

The cost of purchasing fertilizer was higher than the cost of transportation for each of the organic fertilizer treatments (Table 3). OBA + PM gave the highest net return ( $\$ 451766 \mathrm{ha}^{-1}$ ) followed by OBA + GM ( $295208 \mathrm{ha}^{-1}$ ), and the lowest net return ( $137917 \mathrm{ha}^{-1}$ ) was obtained from the NSF (control). All the organic fertilizer treatments, either sole or mixed forms, gave higher net profit over NSF (control). The economic returns and net benefits from sole or mixed forms of organic fertilizer treatments were significantly higher than the IF (NPK) treatment, except for the sole SG treatment, which produced economic returns and net benefit that were similar to IF. Economically, OBA + PM and OBA + GM proved to be more cost effective and profitable than all the other treatments, as shown by their

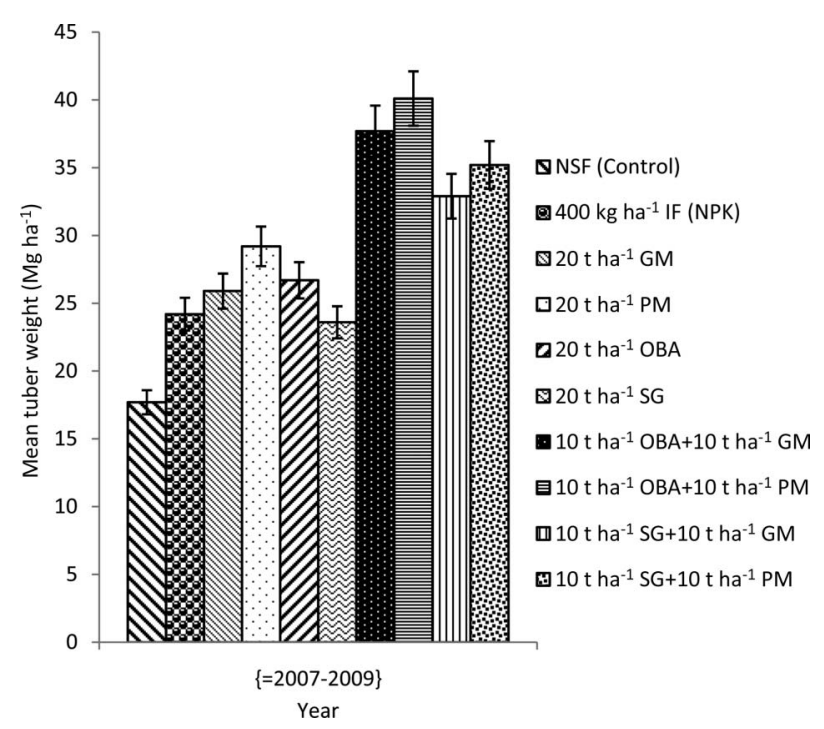

Figure 2. Mean tuber weight from 2007 to 2009 cropping seasons as affected by different organic fertilizers. Vertical bars show standard errors of paired comparisons. 
Archives of Agronomy and Soil Science

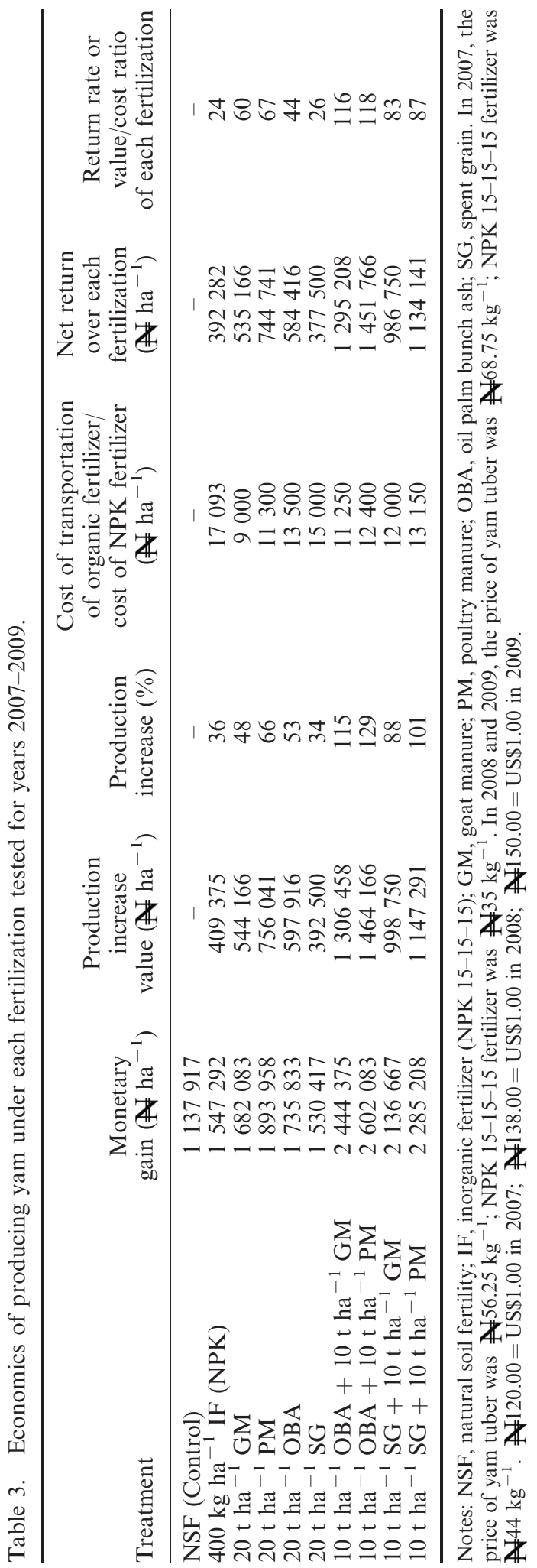


high return rates or value/cost ratios of $118: 1$ and 116:1 for the two organic fertilizers, respectively.

\section{Effect of different organic fertilizers on growth components of yam}

Data on the growth components of yam in 2007, 2008 and 2009 in response to different organic fertilizers are presented in Table 4. Growth parameters such as vine length, number of leaves and leaf area of yam plant increased significantly $(p=0.05)$ under different organic fertilizer treatments compared with NSF (control). In general, the growth components from plots with sole applications were lower than with the various mixtures of organic fertilizers. In the first year and among the sole forms of application, IF gave the highest values for growth parameters, which were not statistically different from PM and GM. In the second and third years, PM and GM gave the highest and similar values for growth parameters. In most cases, the growth parameters produced by these treatments were not significantly different from IF. The SG treatment consistently produced the lowest values of growth parameters, which in most cases were significantly lower than the other treatments, except NSF (control).

Mixed treatments or applications significantly increased $(p=0.05)$ vine length, number of leaves and leaf area. The trends in the values of these parameters in mixed treatments were remarkable in 2007, 2008 and 2009, and were significantly higher $(p=0.05)$ than their sole forms. Among the mixture of OBA and SG with GM and $\mathrm{PM}$, the OBA + PM treatment consistently gave the highest values for vine length, number of leaves and leaf area in the 2007, 2008 and 2009 cropping seasons, followed by $\mathrm{OBA}+\mathrm{GM}, \mathrm{SG}+\mathrm{PM}$ and $\mathrm{SG}+\mathrm{GM}$, respectively. The mean vine length for NSF (control), IF, GM, PM, OBA, SG, OBA + GM, OBA + PM, SG + GM and SG + PM were $2.75,3.36,3.36,3.44,3.23,3.08,4.11,4.20,3.73$ and $3.82 \mathrm{~m}$, respectively. The respective values for number of leaves per plant were 1907, 2463, 2500, 2509, 2355, 2264, 2907, 2977, 2650 and 2728, respectively, and the values for leaf area per plant were $1.41,1.86,1.89,1.96,1.84,1.70,2.57,2.82,2.18$ and $2.35 \mathrm{~m}^{2}$, respectively.

Pooled over the 3 years, OBA + PM increased vine length, number of leaves and leaf area by 30, 26 and 53\%, respectively, compared with OBA (sole). SG + PM increased vine length, number of leaves and leaf area by 13, 9 and $20 \%$, respectively, compared with PM alone. Relative to IF, OBA + PM increased vine length, number of leaves and leaf area by 25, 21 and $52 \%$, respectively. This treatment (OBA + PM) also increased the aforementioned growth parameters by 36,31 and $66 \%$, respectively, compared with sole SG. IF increased the aforementioned growth parameters by 22, 29 and 32\%, respectively, compared with NSF (control).

\section{Effect of organic fertilizers on soil bulk density, total porosity and water content}

In the 3 years of cropping, application of organic fertilizers gave relatively lower soil bulk density, higher total porosity and higher water content compared with NSF (control), whereas application of IF did not influence soil bulk density, total porosity and water content (Table 5). Mixtures of OBA and SG with GM and PM gave similar values for soil bulk density, total porosity and water content, which were not statistically different from one another. In general, the mixture of OBA and SG with GM and PM significantly reduced $(p=0.05)$ soil bulk density and increased total porosity and water content more than their sole applications (GM, PM, OBA and 
Archives of Agronomy and Soil Science

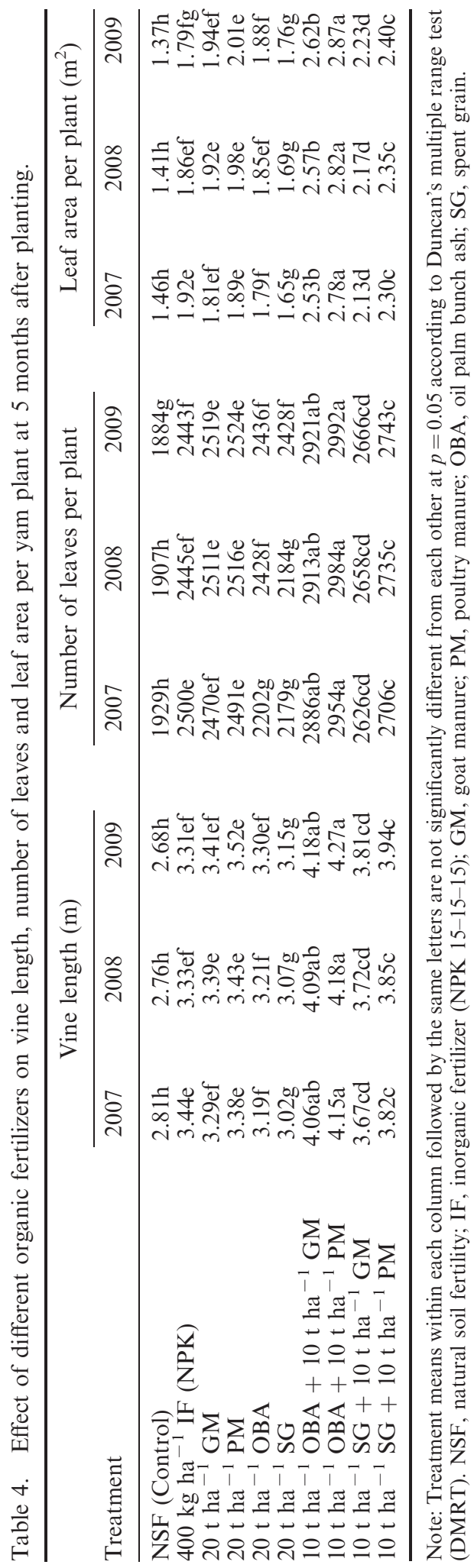


Table 5. Effect of different organic fertilizers on soil physical properties $(0-15 \mathrm{~cm}$ depth) when averaged across four sampling periods $(2,4,6$ and 8 months after planting).

\begin{tabular}{|c|c|c|c|c|c|c|c|c|c|}
\hline \multirow[b]{2}{*}{ Treatment } & \multicolumn{3}{|c|}{$\begin{array}{l}\text { Bulk density } \\
\left(\mathrm{Mg} \mathrm{m}^{-3}\right)\end{array}$} & \multicolumn{3}{|c|}{$\begin{array}{l}\text { Total porosity } \\
\qquad(\%, v / v)\end{array}$} & \multicolumn{3}{|c|}{$\begin{array}{l}\text { Water content } \\
\qquad\left(\mathrm{g} \mathrm{kg}^{-1}\right)\end{array}$} \\
\hline & 2007 & 2008 & 2009 & 2007 & 2008 & 2009 & 2007 & 2008 & 2009 \\
\hline NSF (Control) & $1.38 \mathrm{a}$ & $1.43 \mathrm{a}$ & $1.48 \mathrm{a}$ & $47.9 \mathrm{c}$ & $46.0 \mathrm{c}$ & $44.2 \mathrm{c}$ & $73 \mathrm{c}$ & $81 \mathrm{e}$ & $66 \mathrm{~d}$ \\
\hline $\begin{array}{l}400 \mathrm{~kg} \mathrm{ha}^{-1} \\
\text { IF (NPK) }\end{array}$ & $1.38 \mathrm{a}$ & $1.42 \mathrm{a}$ & $1.47 \mathrm{a}$ & $47.9 \mathrm{c}$ & $46.4 \mathrm{c}$ & $44.5 \mathrm{c}$ & $76 c$ & $80 \mathrm{e}$ & $62 d$ \\
\hline $20 \mathrm{tha}^{-1} \mathrm{GM}$ & $1.16 \mathrm{~b}$ & $1.09 \mathrm{~b}$ & $1.03 \mathrm{~b}$ & $56.2 \mathrm{~b}$ & $58.9 \mathrm{~b}$ & $61.1 \mathrm{~b}$ & $93 b$ & $104 d$ & $122 \mathrm{c}$ \\
\hline $20 \mathrm{t} \mathrm{ha}^{-1} \mathrm{PM}$ & $1.14 \mathrm{~b}$ & $1.07 \mathrm{~b}$ & $1.01 \mathrm{~b}$ & $57.0 \mathrm{~b}$ & $59.6 \mathrm{~b}$ & $61.9 \mathrm{~b}$ & $101 \mathrm{~b}$ & $118 b c$ & $137 \mathrm{~b}$ \\
\hline $20 \mathrm{t} \mathrm{ha}^{-1}$ OBA & $1.18 \mathrm{~b}$ & $1.11 \mathrm{~b}$ & $1.05 \mathrm{~b}$ & $55.5 \mathrm{~b}$ & $58.1 \mathrm{~b}$ & $60.4 \mathrm{~b}$ & $98 b$ & $106 \mathrm{~d}$ & $135 b$ \\
\hline $20 \mathrm{tha}^{-1} \mathrm{SG}$ & $1.19 \mathrm{~b}$ & $1.12 \mathrm{~b}$ & $1.06 \mathrm{~b}$ & $55.1 \mathrm{~b}$ & $57.7 \mathrm{~b}$ & $60.0 \mathrm{~b}$ & $98 \mathrm{~b}$ & $111 \mathrm{~cd}$ & $135 b$ \\
\hline $\begin{array}{c}10 \mathrm{t} \mathrm{ha}^{-1} \mathrm{OBA}+ \\
10 \mathrm{t} \mathrm{ha}^{-1} \mathrm{GM}\end{array}$ & $1.06 \mathrm{c}$ & $0.99 \mathrm{c}$ & $0.93 \mathrm{c}$ & $60.0 \mathrm{a}$ & $62.6 \mathrm{a}$ & $64.9 \mathrm{a}$ & $120 \mathrm{a}$ & $131 \mathrm{a}$ & $158 \mathrm{a}$ \\
\hline $\begin{array}{c}10 \mathrm{t} \mathrm{ha}^{-1} \mathrm{OBA}+ \\
10 \mathrm{t} \mathrm{ha}^{-1} \mathrm{PM}\end{array}$ & $1.04 \mathrm{c}$ & $0.97 \mathrm{c}$ & $0.91 \mathrm{c}$ & $60.8 \mathrm{a}$ & $63.4 \mathrm{a}$ & $65.7 \mathrm{a}$ & $124 \mathrm{a}$ & $136 a$ & $165 \mathrm{a}$ \\
\hline $\begin{array}{l}10 \mathrm{t} \mathrm{ha}^{-1} \mathrm{SG}+ \\
10 \mathrm{t} \mathrm{ha}^{-1} \mathrm{GM}\end{array}$ & $1.06 \mathrm{c}$ & $0.99 \mathrm{c}$ & $0.93 \mathrm{c}$ & $60.0 \mathrm{a}$ & $62.6 \mathrm{a}$ & $64.9 \mathrm{a}$ & $112 \mathrm{a}$ & $126 a b$ & $153 a$ \\
\hline $\begin{array}{l}10 \mathrm{t} \mathrm{ha}^{-1} \mathrm{SG}+ \\
10 \mathrm{t} \mathrm{ha}^{-1} \mathrm{PM}\end{array}$ & $1.05 \mathrm{c}$ & $0.98 \mathrm{c}$ & $0.92 \mathrm{c}$ & $60.4 a$ & $63.0 \mathrm{a}$ & $65.3 \mathrm{a}$ & $118 \mathrm{a}$ & $129 a$ & $155 a$ \\
\hline
\end{tabular}

Note: Treatment means within each column followed by the same letters are not significantly different from each other at $p=0.05$ according to Duncan's multiple range test (DMRT). NSF, natural soil fertility; IF, inorganic fertilizer (NPK 15-15-15); GM, goat manure; PM, poultry manure; OBA, oil palm bunch ash; SG, spent grain.

SG). IF and NSF (control) produced similar values for bulk density, total porosity and water content.

Among the sole forms of the treatment, PM gave the lowest values of soil bulk density, highest total porosity and water content, which were not appreciably different from the values obtained with GM, OBA and SG treatments. Averaged over the 3 years, OBA + PM reduced soil bulk density, and increased total porosity and water content by 47, 37 and 95\%, respectively, compared with IF and NSF (control), whereas application of the sole form of PM reduced soil bulk density, and increased total porosity and water content by 34, 29 and $51 \%$, respectively, compared with IF and NSF (control).

\section{Effect of different organic fertilizers on soil chemical properties}

The results of soil analysis carried out on top soil (0-15 cm depth) at the end of the 2009 cropping season are shown in Table 6. Treatments with organic fertilizers gave significantly higher $(p=0.05)$ values for soil $\mathrm{pH}$, organic $\mathrm{C}$, total $\mathrm{N}$, available $\mathrm{P}$, exchangeable $\mathrm{K}, \mathrm{Ca}$ and $\mathrm{Mg}$ compared with NSF (control). The mixture of $\mathrm{OBA}+\mathrm{PM}$ significantly increased $(p=0.05)$ soil $\mathrm{N}, \mathrm{P}$ and $\mathrm{K}$ concentrations after 3 years of cultivation compared with other treatments. Application of IF significantly increased $(p=0.05)$ soil total $\mathrm{N}$, available $\mathrm{P}$, exchangeable $\mathrm{K}, \mathrm{Ca}$ and $\mathrm{Mg}$ compared with NSF (control), but did decrease soil $\mathrm{pH}$ and organic C. Application of organic fertilizers tended to improve soil $\mathrm{pH}$, organic $\mathrm{C}$, total $\mathrm{N}$, and exchangeable $\mathrm{K}$, $\mathrm{Ca}$ and $\mathrm{Mg}$ more than IF. In general, the mixture of OBA and SG with GM and PM increased soil total $\mathrm{N}$, available $\mathrm{P}$, and exchangeable $\mathrm{Ca}$ and $\mathrm{Mg}$ concentrations more than their sole forms (GM, PM, SG and OBA). 
Table 6. Effect of organic fertilizers on soil chemical properties $(0-15 \mathrm{~cm}$ depth $)$ in 2009 after crop harvest.

\begin{tabular}{|c|c|c|c|c|c|c|c|}
\hline \multirow{2}{*}{ Treatment } & \multirow{2}{*}{$\begin{array}{c}\mathrm{pH} \\
\text { (water) }\end{array}$} & Organic $\mathrm{C}$ & $\mathrm{N}$ & \multirow{2}{*}{$\begin{array}{c}\mathrm{P} \\
\left(\mathrm{mg} \mathrm{kg}^{-1}\right)\end{array}$} & $\mathrm{K}$ & $\mathrm{Ca}$ & $\mathrm{Mg}$ \\
\hline & & \multicolumn{2}{|c|}{$\left(g_{100 g^{-1}}\right)$} & & \multicolumn{3}{|c|}{$\left(\mathrm{cmol} \mathrm{kg}^{-1}\right)$} \\
\hline NSF (Control) & $5.3 \mathrm{ef}$ & $0.72 \mathrm{e}$ & $0.05 \mathrm{j}$ & $5.3 \mathrm{~g}$ & $0.10 \mathrm{~h}$ & $1.07 \mathrm{~h}$ & $0.12 \mathrm{~h}$ \\
\hline $400 \mathrm{~kg} \mathrm{ha}^{-1}$ IF (NPK) & $5.1 \mathrm{f}$ & 0.7 & 0.12 & $24.6 \mathrm{~d}$ & $0.46 \mathrm{~g}$ & $1.47 \mathrm{~g}$ & $0.20 \mathrm{~g}$ \\
\hline $20 \mathrm{t} \mathrm{ha}^{-1} \mathrm{GM}$ & $6.5 \mathrm{c}$ & 2.35 & $0.23 \mathrm{f}$ & $21.0 \mathrm{e}$ & $0.53 \mathrm{f}$ & $2.27 \mathrm{e}^{\circ}$ & $0.69 \mathrm{~d}$ \\
\hline $20 \mathrm{t} \mathrm{ha}^{-1} \mathrm{PM}$ & $6.6 \mathrm{c}$ & $2.74 \mathrm{a}$ & $0.25 \mathrm{e}$ & $23.4 \mathrm{~d}$ & $0.59 \mathrm{e}$ & $2.31 \mathrm{e}$ & $0.66 \mathrm{~d}$ \\
\hline $20 \mathrm{t} \mathrm{ha}^{-1}$ OBA & $7.0 \mathrm{ab}$ & $1.68 \mathrm{~d}$ & $0.20 \mathrm{~g}$ & $22.5 \mathrm{~d}$ & $0.90 \mathrm{~b}$ & $2.78 \mathrm{~d}$ & $0.73 \mathrm{c}$ \\
\hline $20 \mathrm{tha}^{-1} \mathrm{SG}$ & $6.3 \mathrm{~cd}$ & $1.72 \mathrm{~d}$ & $0.16 \mathrm{~h}$ & $20.5 f$ & $0.52 \mathrm{f}$ & $1.75 \mathrm{f}$ & $0.45 \mathrm{e}$ \\
\hline $\begin{array}{l}10 \mathrm{tha}^{-1} \mathrm{OBA}+ \\
10 \mathrm{tha}^{-1} \mathrm{GM}\end{array}$ & $7.0 \mathrm{ab}$ & $2.09 \mathrm{c}$ & $0.36 \mathrm{~b}$ & $30.3 b$ & $0.82 \mathrm{c}$ & $3.86 \mathrm{a}$ & $1.15 \mathrm{a}$ \\
\hline $\begin{array}{c}10 \mathrm{tha}^{-1} \mathrm{OBA}+ \\
10 \mathrm{t} \mathrm{ha}^{-1} \mathrm{PM}\end{array}$ & $7.3 \mathrm{a}$ & $2.18 b c$ & $0.43 \mathrm{a}$ & $36.1 \mathrm{a}$ & $0.98 \mathrm{a}$ & $3.91 \mathrm{a}$ & $1.18 \mathrm{a}$ \\
\hline $\begin{array}{l}10 \mathrm{t} \mathrm{ha}^{-1} \mathrm{SG}+ \\
10 \mathrm{t} \mathrm{ha}^{-1} \mathrm{GM}\end{array}$ & $6.6 \mathrm{c}$ & $2.03 \mathrm{c}$ & $0.28 \mathrm{~d}$ & $26.7 \mathrm{c}$ & $0.75 \mathrm{~d}$ & $3.41 \mathrm{c}$ & $0.87 b$ \\
\hline $\begin{array}{c}10 \mathrm{tha}^{-1} \mathrm{SG}+ \\
10 \mathrm{t} \mathrm{ha}^{-1} \mathrm{PM}\end{array}$ & $6.7 \mathrm{bc}$ & $2.07 \mathrm{c}$ & $0.32 \mathrm{c}$ & $29.3 b$ & $0.78 \mathrm{~cd}$ & $3.64 b$ & $0.91 b$ \\
\hline
\end{tabular}

Note: Treatment means within each column followed by the same letters are not significantly different from each other at $p=0.05$ according to Duncan's multiple range test (DMRT). NSF, natural soil fertility; IF, inorganic fertilizer (NPK 15-15-15); GM, goat manure; PM, poultry manure; OBA, oil palm bunch ash; SG, spent grain

Among the sole forms of treatment, OBA gave significantly higher $(p=0.05)$ values for $\mathrm{pH}, \mathrm{K}, \mathrm{Ca}$ and $\mathrm{Mg}$, whereas $\mathrm{PM}$ gave relatively high soil organic $\mathrm{C}$ and $\mathrm{N}$. $\mathrm{PM}$ also gave the highest soil organic $\mathrm{C}$ concentration compared with sole or mixed applications. With the exception of the mixture of OBA + PM, application of OBA alone gave significantly higher values for $\mathrm{K}$ than sole or mixed applications.

At the end of 3 years of cultivation, OBA $+\mathrm{PM}$ increased soil $\mathrm{pH}$, organic $\mathrm{C}$, total $\mathrm{N}$, available $\mathrm{P}$, exchangeable $\mathrm{K}, \mathrm{Ca}$ and $\mathrm{Mg}$ by 43, 191, 207, 47, 113, 166 and $490 \%$, respectively, compared with IF. The treatment also increased soil $\mathrm{pH}$, total $\mathrm{N}$, available $\mathrm{P}$, exchangeable $\mathrm{K}, \mathrm{Ca}$ and $\mathrm{Mg}$ by 11, 72, 54, 66, 69 and 79\%, respectively, compared with PM alone. However, PM alone increased soil organic C by $26 \%$ compared with a mixture of OBA + PM. In the same vein, OBA + PM also increased soil organic $\mathrm{C}$, total $\mathrm{N}$, available $\mathrm{P}$, exchangeable $\mathrm{K}$, Ca and $\mathrm{Mg}$ by 30, 115, 60, 9, 41 and $62 \%$, respectively, compared with sole application of OBA. However, OBA alone increased soil-exchangeable $\mathrm{K}$ by 10,15 and $20 \%$, respectively, compared with $\mathrm{OBA}+\mathrm{GM}, \mathrm{SG}+\mathrm{PM}$ and $\mathrm{SG}+\mathrm{GM}$. IF increased soil total $\mathrm{N}$, available $\mathrm{P}$, exchangeable $\mathrm{K}, \mathrm{Ca}$ and $\mathrm{Mg}$ by 180,364, 360, 37 and 67\%, respectively, compared with NSF (control). PM alone increased soil $\mathrm{pH}$, organic $\mathrm{C}$, total $\mathrm{N}$, exchangeable $\mathrm{K}, \mathrm{Ca}$ and $\mathrm{Mg}$ by 29, 265, 79, 28, 57 and 230\%, respectively, compared with IF.

\section{Effect of different organic fertilizers on leaf nutrient concentrations of yam}

Both mixtures of organic fertilizers and their sole forms showed significant increases $(p=0.05)$ in leaf $\mathrm{N}, \mathrm{P}, \mathrm{K}, \mathrm{Ca}$ and $\mathrm{Mg}$ concentrations compared with NSF (control) treatment (Table 7 ). The mixed treatment OBA + PM gave the highest leaf $\mathrm{N}, \mathrm{P}, \mathrm{K}$, $\mathrm{Ca}$ and $\mathrm{Mg}$ concentrations and was statistically superior to all other treatments. Among the mixed treatments, leaf $\mathrm{N}, \mathrm{P}, \mathrm{K}, \mathrm{Ca}$ and $\mathrm{Mg}$ concentrations decreases in the following order: $\mathrm{OBA}+\mathrm{PM}>\mathrm{OBA}+\mathrm{GM}>\mathrm{SG}+\mathrm{PM}>\mathrm{SG}+\mathrm{GM}$. These 
Table 7. Effect of different organic fertilizers on leaf nutrient concentrations of yam at 5 months after planting in 2009 cropping season.

\begin{tabular}{lccccc}
\hline Treatment & $\mathrm{N}$ & $\mathrm{P}$ & $\begin{array}{c}\mathrm{K} \\
\left(\mathrm{g} 100 \mathrm{~g}^{-1}\right)\end{array}$ & $\mathrm{Ca}$ & $\mathrm{Mg}$ \\
& & & & \\
\hline NSF (Control) & $1.05 \mathrm{i}$ & $0.14 \mathrm{i}$ & $1.24 \mathrm{~h}$ & $0.11 \mathrm{i}$ & $0.09 \mathrm{i}$ \\
$400 \mathrm{~kg} \mathrm{ha}^{-1} \mathrm{IF}(\mathrm{NPK})$ & $1.64 \mathrm{~h}$ & $0.32 \mathrm{e}$ & $1.44 \mathrm{~g}$ & $0.21 \mathrm{~h}$ & $0.16 \mathrm{~h}$ \\
$20 \mathrm{t} \mathrm{ha}^{-1} \mathrm{GM}$ & $2.14 \mathrm{f}$ & $0.28 \mathrm{fg}$ & $1.62 \mathrm{f}$ & $0.33 \mathrm{f}$ & $0.26 \mathrm{f}$ \\
$20 \mathrm{t} \mathrm{ha}^{-1} \mathrm{PM}$ & $2.37 \mathrm{e}$ & $0.32 \mathrm{e}$ & $1.78 \mathrm{e}$ & $0.41 \mathrm{e}$ & $0.28 \mathrm{f}$ \\
$20 \mathrm{t} \mathrm{ha}^{-1} \mathrm{OBA}$ & $1.89 \mathrm{~g}$ & $0.30 \mathrm{ef}$ & $1.81 \mathrm{e}$ & $0.42 \mathrm{e}$ & $0.33 \mathrm{e}$ \\
$20 \mathrm{t} \mathrm{ha}^{-1} \mathrm{SG}$ & $2.12 \mathrm{f}$ & $0.23 \mathrm{~h}$ & $1.59 \mathrm{f}$ & $0.30 \mathrm{~g}$ & $0.21 \mathrm{~g}$ \\
$10 \mathrm{t} \mathrm{ha}^{-1} \mathrm{OBA}+10 \mathrm{t} \mathrm{ha}^{-1} \mathrm{GM}$ & $3.12 \mathrm{~b}$ & $0.48 \mathrm{~b}$ & $2.43 \mathrm{~b}$ & $0.58 \mathrm{~b}$ & $0.49 \mathrm{~b}$ \\
$10 \mathrm{t} \mathrm{ha}^{-1} \mathrm{OBA}+10 \mathrm{t} \mathrm{ha}^{-1} \mathrm{PM}$ & $3.45 \mathrm{a}$ & $0.54 \mathrm{a}$ & $2.68 \mathrm{a}$ & $0.65 \mathrm{a}$ & $0.55 \mathrm{a}$ \\
$10 \mathrm{t} \mathrm{ha}^{-1} \mathrm{SG}+10 \mathrm{tha}^{-1} \mathrm{GM}$ & $2.64 \mathrm{~d}$ & $0.37 \mathrm{~d}$ & $2.03 \mathrm{~d}$ & $0.47 \mathrm{~d}$ & $0.38 \mathrm{~d}$ \\
$10 \mathrm{t} \mathrm{ha}^{-1} \mathrm{SG}+10 \mathrm{t} \mathrm{ha}^{-1} \mathrm{PM}$ & $2.86 \mathrm{c}$ & $0.42 \mathrm{c}$ & $2.25 \mathrm{c}$ & $0.52 \mathrm{c}$ & $0.43 \mathrm{c}$ \\
\hline
\end{tabular}

Note: Treatment means within each column followed by the same letters are not significantly different from each other at $p=0.05$ according to Duncan's multiple range test (DMRT). NSF, natural soil fertility; IF, inorganic fertilizer (NPK 15-15-15); GM, goat manure; PM, poultry manure; OBA, oil palm bunch ash; SG, spent grain.

mixed treatments also gave significantly higher $(p=0.05)$ leaf $\mathrm{N}, \mathrm{P}, \mathrm{K}, \mathrm{Ca}$ and $\mathrm{Mg}$ concentrations when compared with their sole forms. OBA + PM increased leaf N, $\mathrm{P}, \mathrm{K}, \mathrm{Ca}$ and $\mathrm{Mg}$ concentrations of yam by $110,69,86,210$ and $244 \%$, respectively, compared with IF. The treatment also increased leaf $\mathrm{N}, \mathrm{P}, \mathrm{K}, \mathrm{Ca}$ and $\mathrm{Mg}$ concentrations by 46, 69, 51, 59 and 96\%, respectively, compared with sole application of PM.

All the sole forms of organic treatments significantly increased $(p=0.05)$ leaf $\mathrm{N}$, $\mathrm{Ca}$ and $\mathrm{Mg}$ concentrations compared with IF. Among the sole treatments, PM significantly increased $(p=0.05)$ leaf $\mathrm{N}, \mathrm{P}, \mathrm{K}$ and $\mathrm{Ca}$ concentrations compared with GM and SG. PM was statistically similar to OBA in leaf $\mathrm{K}$ and $\mathrm{Ca}$ concentrations and was significantly higher $(p=0.05)$ in leaf $\mathrm{N}$ than OBA. Similarly, PM was significantly higher $(p=0.05)$ than IF in leaf $\mathrm{N}, \mathrm{K}, \mathrm{Ca}$ and $\mathrm{Mg}$ concentrations by 45 , 24, 95 and 75\%, respectively. The PM treatment also increased leaf N, P, K, Ca and $\mathrm{Mg}$ by $12,39,12,37$ and 33\%, respectively, compared with SG treatment. The IF treatment significantly increased $(p=0.05)$ leaf $\mathrm{N}, \mathrm{P}, \mathrm{K}, \mathrm{Ca}$ and $\mathrm{Mg}$ concentrations by $56,129,16,91$ and $78 \%$, respectively, compared with NSF (control).

\section{Discussion}

The NSF (control) treatment gave the lowest yield and growth parameters for yam, such as tuber weight, vine length, number of leaves and leaf area, leaf and soil total $\mathrm{N}$, available $\mathrm{P}$, exchangeable $\mathrm{K}, \mathrm{Ca}$ and $\mathrm{Mg}$ and soil $\mathrm{pH}$ and organic $\mathrm{C}$. This could be attributed to initial lower nutrient status of the soil and continuous cultivation without fertilization, thus indicating poor soil fertility. The higher soil bulk density of 1.38-1.48 $\mathrm{Mg} \mathrm{m}^{-3}$ recorded for the NSF (control) plots was also not suitable for yam production (Agbede and Ojeniyi 2003). At the end of 3 years of continuous cultivation, soil organic $\mathrm{C}$ decreased by $31 \%$ compared with other treatments, which increases soil organic $\mathrm{C}$. This observation agreed with the study carried out by Adekiya and Agbede (2009), which reported a decrease of $23.8 \%$ in organic C over 2 years of continuous cultivation of tomato crop on an Alfisol at Owo, southwest Nigeria without fertilization. 
However, application of organic fertilizers (solely or as mixtures) to soils with low fertility status enhanced favourable yield and growth parameters of yam, which could be due to their rich nutrient concentrations. This finding agreed with the work of Moyin-Jesu and Ojeniyi (2006), which reported a rapid response in the yield and growth of okra with the application of organic fertilizers. Hence, this finding highlighted the importance of organic fertilizer use for the enhancement of soil and crop productivity in the tropics.

After three cropping seasons, OBA $+\mathrm{PM}$ applied at suboptimal rates $\left(10 \mathrm{t} \mathrm{ha}^{-1}\right.$ each) significantly increased yield and growth parameters of yam, soil and leaf $\mathrm{N}, \mathrm{P}$, $\mathrm{K}$, $\mathrm{Ca}$ and $\mathrm{Mg}$, and increased soil $\mathrm{pH}$ and organic $\mathrm{C}$ compared with either sole or mixed applications of organic fertilizers. This could be attributed to its higher nutrient concentrations ( $\mathrm{N}, \mathrm{P}, \mathrm{K}, \mathrm{Ca}$ and $\mathrm{Mg}$ ), which increased the availability of nutrients in the soil, leading to increased uptake by yam plants. In addition, another reason could be due to increased microbial activities and mineralization of nutrients induced by the addition of PM, which should have facilitated nutrient release and increased production of nutrients.

The effectiveness of OBA and SG in enhancing/improving yield and growth parameters of yam, leaf and soil $\mathrm{N}, \mathrm{P}, \mathrm{K}, \mathrm{Ca}$ and $\mathrm{Mg}$, and soil $\mathrm{pH}$ and organic $\mathrm{C}$, when mixed with GM and PM could be attributed to the enhancement of their biodegradation rate by manures with a lower $\mathrm{C} / \mathrm{N}$ ratio. In addition, the processing of organic fertilizers before application to the soil should have further facilitated their decomposition and rate of nutrient release to the soil. However, the deleterious effect of continuous application of chemical fertilizer in enhancing soil and crop productivity was clearly shown after 3 years of cropping because the IF (NPK) resulted in significantly lower $(p=0.05)$ leaf $\mathrm{N}, \mathrm{K}, \mathrm{Ca}$ and $\mathrm{Mg}$ compared with either mixed or sole application of organic fertilizers. This may be due to loss of nitrogen through the leaching of nutrients beyond the sampling depth $(0-15 \mathrm{~cm}$ depth). The decrease in the soil-exchangeable $\mathrm{K}$ concentration over time was probably due to the exhaustive use of soil $\mathrm{K}$ by the yam plant for tuber formation. Also, part of the soil-exchangeable $\mathrm{K}$ could have been lost to leaching. This study agreed with the findings of Agboola and Omueti (1982) that continuous use of inorganic fertilizers resulted in the serious deterioration of soil properties and poor yield responses, whereas repeated application of organic fertilizers to soil has been shown to improve physicochemical properties (Mbagwu 1992; Kingery et al. 1993; Moyin-Jesu and Adeofun 2008). The increases in soil and leaf $\mathrm{N}, \mathrm{P}, \mathrm{K}, \mathrm{Ca}$ and $\mathrm{Mg}$ concentrations attributed to IF (NPK fertilizer) compared with control might be due to high soluble and plant-available nutrients, as well as the decomposition of organic matter and mineralization of its nutrients.

The superlative performance of the OBA + PM treatment in increasing tuber weight, vine length, number of leaves and leaf area of yam compared with IF (NPK) could be a result of their improvement in soil physical properties (reduced soil bulk density, increased total porosity and water content), highest nutrient amounts provided ( $\mathrm{N}, \mathrm{P}, \mathrm{K}, \mathrm{Ca}$ and $\mathrm{Mg}$ ), which increased the availability of soil nutrients and their subsequent uptake by yam plants. Low soil bulk density and high total porosity and water content are known to enhance root growth and uptake of $\mathrm{N}, \mathrm{P}$ and especially $\mathrm{K}$ that is essential for yam. The lower yield and growth components recorded for IF (NPK) was consistent with higher soil bulk density and relatively low soil and leaf N, P and K concentrations recorded for IF (NPK). The mean soil bulk 
density recorded for the IF (NPK) $\left(1.47 \mathrm{Mg} \mathrm{m}^{-3}\right.$ ) was almost above the value of 1.1 $\mathrm{Mg} \mathrm{m}^{-3}$ found to be suitable for yam tuber formation (Agbede and Ojeniyi 2003).

The higher values of tuber weight, vine length, number of leaves and leaf area, soil $\mathrm{N}, \mathrm{P}, \mathrm{K}, \mathrm{pH}$ and organic $\mathrm{C}$ in the $\mathrm{OBA}+\mathrm{PM}$ treatment applied at $10 \mathrm{t} \mathrm{ha}^{-1}$ each compared with $\mathrm{OBA}+\mathrm{GM}$ and $\mathrm{SG}+\mathrm{PM}$ at $\left(10 \mathrm{t}\right.$ ha ${ }^{-1}$ each $)$ might be because $\mathrm{PM}$ had the highest $\mathrm{N}$ and $\mathrm{P}$ concentrations and the lowest $\mathrm{C} / \mathrm{N}$ ratio, whereas OBA had the highest $\mathrm{K}, \mathrm{Ca}$ and $\mathrm{Mg}$ concentrations. This affirmed the positive cumulative effect of that combination. Yam performance is known to be strongly influenced by N and K (Obigbesan 1981, 1999; Akanbi and Ojeniyi 2007). This finding was similar to the work of Moyin-Jesu and Adeofun (2008), who reported the best performance for OBA + PM in increasing growth, soil and leaf nutrient concentrations in bitter kola seedlings.

The better performance of the mixture of OBA and SG with GM and PM over their sole forms was attributable to their solubilizing effects and the fact that PM and GM have high nutrient concentrations and low $\mathrm{C} / \mathrm{N}$ ratios and their mixture with OBA and SG increased/ fortified their nutrient supplying power. This also affirmed that mixed application of organic fertilizers may be more useful for nutrient addition to soil than sole applications of organic fertilizers.

The better performance of OBA in comparison with IF (NPK) after 3 years of cultivation could be attributed to increased soil organic $\mathrm{C}$, its buffering action against $\mathrm{pH}$ fluctuation and leaching, improved soil structure and water retention capacity due to OBA addition and its relatively higher K. Potassium was reported to be an important nutrient in the production of yam (Obigbesan 1999).

The increase in tuber weight of yam over time in the organic fertilizer treatments could be attributed to their high residual effects on soil properties and were able to sustain three successive cropping of yam in this study. Whereas the decrease in tuber weight of yam over time in the IF (NPK) treatment was related to the fact that nutrients from IF are quickly released into soil, which may not benefit subsequent yam crops and its continuous application degrades soil properties.

The sole organic fertilizer applied at $20 \mathrm{tha}^{-1}$ and the mixture of OBA and SG with GM and PM applied at suboptimal rates (10 $\mathrm{t} \mathrm{ha}^{-1}$ each) generally reduced soil bulk density and increased water content and porosity compared with IF (NPK) and NSF (control). The observed trend in these soil physical properties may be due to significant organic matter addition to the soil by organic amendments, which provided stable soil aggregate conditions and prevented leaching/eroding of colloidal fraction with high 'enrichment ratio' and valuable nutrients from soil. The effects of GM, PM, OBA and SG in reducing soil bulk density and increasing water content and porosity were attributable to the increase in organic matter status of the soil because organic amendments are known to stabilize soil structure, enhance soil porosity and water infiltration and retention (Ojeniyi et al. 2007; Agbede and Ojeniyi 2010). This study agreed with the findings of Mbagwu and Piccolo (1989) that repeated application of organic residues to soil improves physicochemical properties of such soils. Vinten et al. (2002) also reported an increase in microbial activity following application of organic amendments to soil, thus suggesting a more responsive microbial community. The importance of beneficial microbes in building a healthy soil microenvironment through enhancement of natural soil process cannot be overemphasized.

The increase in soil $\mathrm{pH}$ observed under OBA alone or when mixed with GM and $\mathrm{PM}$ compared with other treatments was attributable to its high $\mathrm{K}$, $\mathrm{Ca}$ and $\mathrm{Mg}$ 
concentrations. This could be due to the liming effects of plant ash on the soil (Azeez et al. 2007; Moyin-Jesu and Adeofun 2008) unlike IF (NPK), which could lead to soil acidity (decrease soil $\mathrm{pH}$ ) with repeated use. The increase in soil $\mathrm{pH}$ recorded for sole applications of PM and GM compared with IF (NPK) could be attributed to the increased availability of organic matter and calcium ions released into the soil solution during the microbial decarboxylation of manures (Agbede 2010), which is known to buffer change in soil $\mathrm{pH}$.

Nutrient concentrations in the leaves of yam plants in the NSF (control) plots were below the critical levels of $<2.9-4.0 \% \mathrm{~N}, 0.21-0.32 \% \mathrm{P}, 2.2-2.8 \% \mathrm{~K}, 0.5-$ $0.9 \% \mathrm{Ca}$ and $0.10-0.14 \% \mathrm{Mg}$, as reported by O'Sullivan (2010), thus the leaves of yam plants exhibited symptoms of deficiencies in $\mathrm{N}$ (yellow colouration), $\mathrm{P}$ (purple colouration) and $\mathrm{K}$ (burnt leaf margin).

The application of GM and PM, OBA and SG (either solely or as mixtures) including the IF (NPK) increased the leaf $\mathrm{N}, \mathrm{P}, \mathrm{K}, \mathrm{Ca}$ and $\mathrm{Mg}$ concentrations of yam plants compared with NSF (control), which could be attributed to their leaf nutrient concentrations (Table 7). This observation agreed with the study of Moyin-Jesu and Adeofun (2008), which reported that PM, turkey manure, OBA and SG were good sources of $\mathrm{N}, \mathrm{P}, \mathrm{K}, \mathrm{Ca}$ and $\mathrm{Mg}$ when applied to soils.

\section{Conclusion}

The sole forms of organic fertilizer applied at $20 \mathrm{t} \mathrm{ha}^{-1}$ each and a mixture of OBA and SG with GM and PM applied at $10 \mathrm{t} \mathrm{ha}^{-1}$ each increased tuber weight, vine length, number of leaves and leaf area of yam and reduced bulk density and increased total porosity, water content, soil and leaf $\mathrm{N}, \mathrm{P}, \mathrm{K}, \mathrm{Ca}$ and $\mathrm{Mg}$, soil $\mathrm{pH}$ and organic C compared with the NSF (control). IF (NPK 15-15-15 fertilizer) did not improve soil physical properties, but did increase soil and leaf nutrient concentrations, growth and yield of yam compared with the NSF (control). $\mathrm{OBA}+\mathrm{PM}$ applied at $10 \mathrm{tha}^{-1}$ each gave the highest yam tuber yield due to its higher $\mathrm{N}, \mathrm{P}, \mathrm{K}, \mathrm{Ca}, \mathrm{Mg}$, total porosity, water content and lower bulk density and relatively low $\mathrm{C} / \mathrm{N}$ ratio compared with other treatments and therefore recommended for yam production on an Alfisol of the humid tropics for improving soil fertility conditions and sustained productivity. This recommendation agreed with the fact that inorganic fertilizers are very scarce, expensive to purchase by small holding farmers of yam and also destroy soil properties when use repeatedly. These organic materials are cheap, available and sustainable, and also have beneficial secondary effects on soil properties and are more favourable to the environment.

\section{References}

Adekiya AO, Agbede TM. 2009. Growth and yield of tomato (Lycopersicon esculentum Mill) as influenced by poultry manure and NPK fertilizer. Emir J Food Agr. 21(1):10-20.

Adu-Dapaah HK, Cobbinah J, Asare EO. 1994. Effect of cocoa pod ash on the growth of maize. J Agr Sci. 122:31-33.

Aduayi EA. 1980. Effect of ammonium sulphate fertilization on soil chemical composition, fruit yield, and nutrient content of okra. Ife J Agr. 2(1):16-33.

Agbede TM. 2006. Effect of tillage on soil properties and yam yield on an Alfisol in southwestern Nigeria. Soil Till Res. 86:1-8.

Agbede TM. 2010. Tillage and fertilizer effects on some soil properties, leaf nutrient concentrations, growth and sweet potato yield on an Alfisol in southwestern Nigeria. Soil Till Res. 110:25-32. 
Agbede TM, Ojeniyi SO. 2003. Effect of land preparation methods on soil properties and yield of yam grown on an Alfisol. Nigerian J Soil Sci. 13:68-75.

Agbede TM, Ojeniyi SO. 2009. Tillage and poultry manure effects on soil fertility and sorghum yield in southwestern Nigeria. Soil Till Res. 104:74-81.

Agbede TM, Ojeniyi SO. 2010. Tillage and poultry manure effects on soil physical properties, nutrient status, growth, dry matter and grain yield of sorghum. J Agr Sci Tech. 4(3):45-59.

Agbede TM, Ojeniyi SO, Adeyemo AJ. 2008. Effect of poultry manure on soil physical and chemical properties, growth and grain yield of sorghum in southwest Nigeria. Am Eurasian J Sustain Agr. 2(1):72-77.

Agboola AA, Omueti JA. 1982. Soil fertility problem and its management in the tropical Africa. Paper Presented at the International Institute of Tropical Agriculture (IITA), Ibadan, Nigeria. p. 25.

Akanbi SO, Ojeniyi SO. 2007. Effect of siam weed mulch on soil properties and performance of yam in southwest Nigeria. Nigerian J Soil Sci. 17:120-125.

Akinrinde EA, Obigbesan GO. 2000. Evaluation of the fertility status of selected soils for crop production in five ecological zones of Nigeria. In: Babalola O, editor. Proceedings of the 26th Annual Conference of Soil Science Society of Nigeria; 2000 Oct 30-Nov 3; Ibadan, Nigeria. p. 279-288.

Ano AO, Agwu JA. 2005. Effect of animal manure on selected soil chemical properties (I). Nigerian J Soil Sci. 15:14-19.

Ayeni LS, Ayeni OM, Oso OP, Ojeniyi SO. 2008. Effect of sawdust and woodash application in improving soil chemical properties and growth of cocoa (Theobroma cacao) seedlings in nurseries. Agr J. 2(5):323-326.

Azeez JO, Adetunji MT, Adebusuyi B. 2007. Effect of residue burning and fertilizer application on soil nutrient dynamics and dry grain of maize (Zea mays L.) in an Alfisol. Nigerian J Soil Sci. 17:71-80.

Bationo A, Kihara J, Vanlauwe B, Waswa B, Kimetu J. 2006. Soil organic carbon dynamics, functions and management in West African agroecosystems. Agr Syst. 94:13-25.

Bremner JM. 1996. Nitrogen-total. In: Sparks DL, editor. Methods of soil analysis. Part 3. Chemical methods. 2nd ed. SSSA Book Series No. 5. Madison (WI): ASA and SSSA. p. $1085-1121$.

Carter MR. 1993. Soil sampling and methods of analysis. Canadian Society of Soil Science. Boca Raton (FL): Lewis. 823 pp.

Degras L. 1993. The yam: a tropical root crop. London: Macmillan/ The Technical Centre for Agricultural and Rural Cooperation.

FAO. 1998. World reference base for soil resources World Soil Resources Report 84. Rome (Italy): Foods and Agriculture Organisation of the United Nations.

Fertilizer Procurement and Distribution Division (FPDD). 1989. Fertilizer uses and management practices for crops in Nigeria. Lagos (Nigeria): Federal Ministry of Agriculture and Water Resources and Rural Development. 163 pp.

Frank K, Beegle D, Denning J. 1998. Phosphorus. In: Brown JR, editor. Recommended chemical soil test procedures for the North Central Region. North Central Regional Research Publication No. 221 (revised). Columbia (MO): Missouri Agric. Exp. Stn. p. $21-26$.

Gruhn P, Goletti F, Yudelman M. 2000. Integrated nutrient management, soil fertility, and sustainable agriculture. Current issues and future challenges. Available from http:// www.ifpri.org/2020/briefs/ number 67.htm.

Horwitz W, editor. 1997. Official methods of analysis of the Association of Official Analytical Chemists International, 16th ed. Gaithersburg (MD): AOAC International. $1298 \mathrm{pp}$.

Howeler RH, Ezumah HC, Midmore DJ. 1993. Tillage systems for root and tuber crops in the tropics. Soil Till Res. 27:211-240.

Ikpe FN, Powel JM. 2003. Nutrient cycling practices and changes in soil properties in the crop livestock farming system of west Niger Republic of West Africa. Nutr Cycl Agroeco. 62:37-45.

Kingery WL, Wood CW, Delaney DP. 1993. Impact of long-term application of broiler litter on environmentally related soil properties. J Environ Qual. 23:139-147.

Maritus CHT, Vleic PLG. 2001. The management of organic matter in tropical soils: What are the priorities? Nutr Cycl Agroecol. 61:1-16. 
Mbagwu JSC. 1992. Improving the productivity of a degraded Ultisol in Nigeria using organic and inorganic amendments II. Changes in physical properties. Bioresourc Tech. 42:167-175.

Mbagwu JSC, Piccolo A. 1989. Changes in soil aggregate stability induced by amendment with humic substances. Afr J Biotech. 5:1058-1061.

Moyin-Jesu EI, Adeofun CO. 2008. Comparative evaluation of different organic fertilizers on the soil fertility, leaf mineral composition and growth of bitter Kola seedlings. Emir J Food Agr. 20(1):31-45.

Moyin-Jesu EI, Atoyosoye B. 2002. Utilization of Agricultural wastes for the growth, leaf and soil chemical composition of cocoa seedlings in the Nursery. Pertanika J Trop Agr Sci. 25(1):53-63.

Moyin-Jesu EI, Ojeniyi SO. 2006. Effects of sole and amended plant residues on soil nutrient contents and yield of okra (Abelmoschus esculentum L.). Discov Innov J. 18 (4):318-326.

Nelson DW, Sommers LE. 1996. Total carbon, organic carbon and organic matter. In: Sparks DL, editor. Methods of soil analysis. Part 3. 2nd ed. SSSA Book Series No. 5. Madison (WI): ASA and SSSA. p. 961-1010.

Nottidge DO, Ojeniyi SO, Asawalam DO. 2005. Comparative effects of plant residues and NPK fertilizer on soil properties in a humid Ultisol. Nigerian J Soil Sci. 15:9-13.

National Root Crop Research Institute (NRCRI). 1982. Annual Report. Umudike (Nigeria): National Root Crop Research Institute. p. 6.

Obigbesan GO. 1981. Nutrient requirements of yams. Agriculture Research Bulletin, University of Ibadan, Nigeria 12(1):1-20.

Obigbesan GO. 1999. Fertilizer: Nigerian farmers' dilemma. Inaugural lecture, University of Ibadan, Nigeria. 37 pp.

Obigbesan GO, Agboola AA. 1978. Uptake and distribution of nutrients by yams (Dioscorea spp) in western Nigeria. Exp Agr. 14:349-355.

Ohiri AC. 1995. Soil physical and chemical conditions favourable for yam (Dioscorea sp.) growth and tuber development in Nigeria. Afr Soil. 28:231-242.

Ojeniyi SO. 2000. Effect of goat manure on soil nutrient and okra yield in a rainforest area of Nigeria. Appl Trop Agr. 5:20-23.

Ojeniyi SO, Akanni DA, Awodun MA. 2007. Effect of goat manure on soil properties and growth, yield and nutrient status of tomato. Univ Khartoum J Agr Sci. 15(3):396-406.

Okalebo JR, Gathua KW, Woomer PL. 2002. Laboratory methods of soil and plant analysis. A working manual. 2nd ed. Nairobi (Kenya): TSBF-CIAT, SACRED Africa, KARI, SSEA. 128 pp.

Okereke JE, Njoku BO, Ohiri AC, Igbokwe MC, Ewe LSO, editors. 1987. In: Proceedings of the National Fertilizer Seminar, Oct 28-30, 1987. Port Harcourt. Fertilizer Procurement and Distribution Division/Federal Ministry of Agriculture and Water Resources and Rural Development (FPDD/FMAWRRD).

Okoh CA. 2004. The effect of mulching on soil physico-chemical properties and the yield of white yam. Trop J Root Tuber Crop. 4(2):24-31.

Onweremadu EU, Ibeawuchi II, Duruigbo CI. 2008. Land evaluation and productivity of organically-fertilized crop mixtures in a degraded tropical soil. Nat Sci. 6(1):34-42.

Onwueme IC. 1978. The tropical tuber crops: yams, cassava, sweet potato and cocoyams. New York: Wiley.

Orkwor GC, Asiedu R, Ekanayake IJ. 1998. Food yams advances in research. Ibadan (Nigeria): International Institute of Tropical Agriculture (IITA)/Umudike (Nigeria): National Root Crops Research Institute,. 239 pp.

O'Sullivan JN. 2010. Yam nutrition: nutrient disorders and soil fertility management. ACIAR Monograph No. 144. Canberra: Australian Centre for International Agricultural Research. 112 pp.

Samuel RC, Ikepe FN, Osakwe JA, Tenkonamo A, Okerter IC. 2003. Effects of wood based compost and fertilizer application on the growth and yield of a cooking banana hybrid and soil chemical properties in southeastern Nigeria. Afr J Environ Stud. 4:64-68.

Sheldrick B, Hand Wang C. 1993. Particle-size distribution. In: Carter MR, editor. Soil sampling and methods of analysis. Ann Arbor (MI): Canadian Society of Soil Science/ Lewis. p. 499-511.

Shiwachi H, Okonkwo CC, Asiedu R. 2004. Nutrient deficiency symptoms in yams (Dioscorea spp). Trop Sci. 44:155-162. 
Steel RGD, Torrie JH, Dickey DA. 1997. Principles and procedures of statistics. A biometrical approach. 3rd ed. New York: McGraw-Hill.

United States Department of Agriculture (USDA). 2010. Soil taxonomy. 11th ed. Agriculture Handbook, No. 436. Washington (DC): United States Department of Agriculture, Natural Resources Conservation Services.

Vernier P, Dansi P. 2000. Participatory assessment and farmers' knowledge on yam varieties (D. rotundata and D. cayanesis) in Benin. Paper presented at the ISTRC 2000 Symposium, Isukuba, Ibaraki, Japan; Sept 10-16. p. 1-17.

Vinten AJA, Whitmore AP, Bloem J, Howard R, Wright F. 2002. Factors affecting N immobilization/mineralization kinetics for cellulose, glucose and straw amended sandy soils. Bio Fertil Soil. 36:190-199.

Yadav RL, Prassad SR. 1992. Conserving the organic matter content of soil to sustain sugarcane yield. Exp Agr. 28:51-52. 